Ege Tıp Dergisi / Ege Journal of Medicine 2020; 59 (2): 140-143

\title{
Yıldırım çarpması sonrası hayatta kalan bir olgunun adli-tıbbi değerlendirmesi
}

Medicolegal evaluation of a case who survived by a lightning strike

\author{
Ahsen Kaya B Burcu Özçalışkan $(D$ Selen Can Temürkol(D) Uğur Ata \\ Ege Üniversitesi, Tıp Fakültesi, Dahili Tıp Bilimleri Bölümü, Adli Tıp Anabilim Dalı, İzmir, Türkiye
}

Öz

Yıldııım; ölümle sonuçlanabilen ve en sık karşılaşılan hava kaynaklı doğa olayı olup anlık, atmosferik, geçici, yüksek akımlı elektriksel deşarj olarak tanımlanmaktadır. Bu çalışmada; yıldırım çarpması sonrası hayatta kalan olgunun bulgularının literatür eşliğinde tartışılması ve adli-tıbbi yönden değerlendirilmesi amaçlandı.

Nisan 2018'de askerlik hizmetini yaparken, yağmurlu bir havada, 2000 metre yükseklikte, açık alanda yıldırım çarpması sonucu yaralanan 28 yaşındaki erkek olgu, polikliniğimize adli raporunun düzenlenmesi için başvurdu. Olay tarihli tıbbi evrakında, alt ve üst ekstremitelerde yanık alanları, nonspesifik EKG değişiklikleri, karaciğer fonksiyon testi yüksekliği ve sol testiste inflamasyon bulguları olduğu yazılıydı. Olaydan sekiz ay sonra tarafımızca yapılan muayenesinde skar dokuları dışında başka bir bulgu saptanmadı.

Literatürde, yıldırım çarpması sonucu meydana gelen bulgular daha çok otopsi bulguları ile sınırlıdır. Yıldırım çarpması sonrası hayatta kalan bu olgunun bulgularının literatüre katkı sağlayacağı düşünüldü.

Anahtar Sözcükler: Yıldırım çarpması, adli tıp, adli olgu, yanık.

\begin{abstract}
Lightning is the most common airborne nature event that can result with death and is defined as instantaneous, atmospheric, and transient, high-current electrical discharge. This study's aim is to discuss the findings of the patient who survived a lightning strike in the light of literature and to evaluate medicolegal aspects.

A 28-year-old male case who was injured by lightning strikes in a rainy weather, at heights of 2000 meters, in the open field while having his military service in April 2018, applied to our policlinic for his forensic report. In his medical records, burns in his lower and upper extremities, nonspecific ECG changes, elevated liver function tests and left testis inflammation were documented. Eight months after the event we revealed no signs except scar tissues.

In the literature, lightning strike findings are mostly about the autopsy findings. We thought that the findings of this survived case would contribute to the literature.
\end{abstract}

Keywords: Lightning, forensic medicine, forensic case, burn.

Sorumlu yazar: Burcu Özçalışkan

Ege Üniversitesi, Tıp Fakültesi, Dahili Tıp Bilimleri Bölümü,

Adli Tıp Anabilim Dalı, İzmir, Türkiye

E-posta: burcuozcaliskan@windowslive.com

Başvuru tarihi: 06.08.2019 Kabul tarihi: 25.11.2019 


\section{Giriş}

Yıldırım; anlık, atmosferik, geçici ve yüksek akımlı elektriksel deşarj olarak tanımlanmaktadır (1-3). Yıldırım deşarjlarının çoğu bulutların içinde oluşurken, bazıları buluttan toprağa elektrik boşalmasına ve bir fırtına bulutunun tabanı ile yeryüzü arasındaki devrenin tamamlanmasına neden olmaktadır (1-3). Yıldırımdan açığa çıkan enerjinin yaklaşık 30 milyon volt ve 30-50 bin amper şiddetinde olduğu, açığa çıkan ISI enerjisinin yaklaşık 30 bin kalori, basıncın 100 atmosfer basınca ulaştığı, süresinin de saniyenin 1/1000'i kadar olduğu belirtilmektedir (4).

Yıldırım, ölümle sonuçlanabilen ve en sık karşılaşılan hava kaynaklı doğa olaylarından biri olup yıldırım çarpmasına bağlı insan ölümlerinin çoğu, buluttan toprağa yıldırım çarpması sonucu meydana gelmektedir $(1,3)$. İnsanlar yıldırım çarpmalarını, yıldırımın düştüğü topraktan akım etkisi dışında, direkt etki, yıldırımın düştüğü cisme/kişiye temas, sıçrama etkisi gibi şekillerde tecrübe edebilmekte ve bulgular etki şekline göre değişiklik gösterebilmektedir $(5,6)$. Genel olarak, direkt etki ile meydana gelen yaralanmaların morbiditesi yüksek olup, sıçrama etkisi ile vücudun isabet alan kısımlarında alev yanığı benzeri hasarlar oluşabilmekte, topraktan çarpan akımlarda ise aritmi ve asistoli gelişimi sık görülebilmektedir (5). Bu çalışmada; yıldırım çarpması sonrası hayatta kalan olgunun bulgularının literatür eşliğinde tartışılması ve adlitıbbi yönden değerlendirilmesi amaçlanmıştır.

\section{Olgu Sunumu}

Adli raporunun düzenlenmesi için polikliniğimize başvuran 28 yaşındaki erkek olgu, Nisan 2018'de askerlik hizmetini yaparken, yağmurlu bir havada, 2000 metre yükseklikte, açık alanda yıldırım çarptığını, olaydan hemen sonra bulunduğu yerdeki devlet hastanesine götürüldüğünü, ardından sevk edildiği yanık merkezinde üç ay tedavi gördüğünü, yıldırımdan nasıl etkilendiğini hatırlamadığını ancak olay yerinde bir arkadaşının da yıldırım çarpması nedeniyle kalp krizi geçirdiğini beyan etti.

Olay tarihli tıbbi evrakında, yıldırım çarpması sonucu, sol dirsek ve ön kolda, sol uyluk iç yüzde, sol uyluk ön yüzde ve sağ ayak sırtında olmak üzere toplam \%8'lik ikinci derece yanık alanlarının olduğu kayıtlıydı.

Tablo-1. Yıldırım çarpması sonucu görülebilen bulguların olgumuzdaki bulgularla karşılaştııılması.

\begin{tabular}{|c|c|}
\hline Yıldırım Çarpması Sonucu Görülebilen Bulgular* & Olgumuzdaki Bulgular \\
\hline Bulgu yok & - \\
\hline Cilt yanıkları & + \\
\hline Saç, kıl yanığı & + \\
\hline Lichtenberg Figürleri & - \\
\hline Beyin hasarı (hemoraji, parankim hasarı vb) & - \\
\hline Hipoksik-iskemik ensefalopati & - \\
\hline Omurilik hasarı (direkt ya da kırık sonrası) & - \\
\hline Periferik nöropati & - \\
\hline Kulak zarı yırtılması & - \\
\hline Göz lezyonları & - \\
\hline Kas nekrozu & + \\
\hline Kemik kırıkları & - \\
\hline Akciğer kontüzyonu & - \\
\hline Miyokart hasarı & - \\
\hline Renal hasar, miyoglobüniri & - \\
\hline Testiste inflamasyon, hidrosel & + \\
\hline Nonspesifik EKG değişikliği & $+(U$ dalgası $)$ \\
\hline Karaciğer fonksiyon testi yüksekliği & $+(\mathrm{AST}, \mathrm{ALT}, \mathrm{LDH})$ \\
\hline Psikopatoloji & - \\
\hline Kardiyak arrest & - \\
\hline Ölüm & - \\
\hline
\end{tabular}

*: Bulgular 3, 7 ve 8 numaralı kaynaklardan derlenmiştir. 
Sol dirsek ve ön kol dorsal yüzeyindeki yaklaşık $10 \times 15 \mathrm{~cm}$ 'lik yaraya yanık debritmanı ile VAC (Vacuum Assisted Closure) yapıldığı, ardından bu bölgeye sağ uyluk ön yüzden alınan kısmi kalınlıkta deri greftinin uygulandığı yazılıydı.

Sunulan olguda görülen yanık lezyonları dâhil tüm bulguların yıldırım çarpması sonucu görülebilecek bulgularla karşılaştırması Tablo1 'de gösterilmiştir.

Olgunun olaydan sekiz ay sonra tarafımızca yapılan muayenesinde skar dokuları dışında fiziksel bir bulgu saptanmadı. Sol dirsek hareketlerinde zorlanma ve sol dirsekte greftli alanda duyu kaybı şikâyetleri olan olgunun bilateral dirsek ve ayak bileği eklem hareket açıklıklarının ve kas gücünün normal olduğu saptandı. Psikolojik bir şikâyet tarif edilmedi.

\section{Tartışma}

Dünyada yıldırıma bağlı yaralanmalar bilinenin aksine kış aylarında değil, genellikle yaz aylarında artış göstermektedir (2). Yıldırıma bağlı yaralanmaların Amerika Birleşik Devletleri'nde Temmuz'da, Hindistan'da ise muson yağmurlarının görüldüğü Temmuz-Eylül ayları arasında artış gösterdiği belirtilmektedir (2). Kampçılar, yürüyüşçüler, çiftçiler, yapı işçileri, golf oynayanlar ve avcılar gibi dışarıda, yüksek yerlerde çalışan veya aktivite gösterenler yıldırım çarpmasına en sık maruz kalan insanlardır. Ev içindeki mağdurlar ise özellikle telefon, televizyon ya da elektrikli diğer ev aletlerini kullananlardır (5). Olgumuz bahar mevsiminde, Nisan ayında literatürle uyumlu olarak da yağmurlu havada, 2000 metre yükseklikte, açık alanda askerlik yapmakta iken yıldırım çarpmasına maruz kalmıştır.

Yıldırım çarpması olgularında vücutta herhangi bir bulgu görülmeyebileceği gibi, yanık, elektrik giriş ve çıkış yaraları veya elbiselerde parçalanma görülebilmektedir (7). Literatürde; yıldırım çarpması sonucu olguların \%20-30'unun ölümle sonuçlandığı, ölümle sonuçlanan olgularda başlıca nedenin primer ventriküler yetmezlik veya asistol ile ilişkili olduğu belirtilmiştir $(9,10)$. Ölümle sonuçlanmayan yıldırım çarpması olgularında ise özellikle ortopedik ve nörolojik sekeller meydana geldiği, fizik tedavi yanı sıra uzun süreli psikiyatrik ve nörolojik tedavi gerekebildiği bildirilmiştir $(7,9$, 10). Olgumuzda literatürden farklı olarak skar dokuları dışında herhangi bir ortopedik sekel kalmadan iyileşmenin söz konusu olduğu, psikolojik ya da nörolojik bir bulgunun bulunmadığı görülmüştür. Bu durum, ölüm dahil çoğunlukla travma bulguları ile sonuçlanan yıldırım çarpmalarında, bu olguda olduğu gibi skar dokuları dışında herhangi bir kalıcı bulgu olmaması nadir görülen bir durum olup, yıldırıma maruz kalmanın doğrudan değil de sıçrama etkisi ile oluşmuş olabileceği kanaatini oluşturmuştur.

Yıldırım çarpmasının bir doğa olayı olması, kimi zaman sağlık çalışanlarında bu durumun adli bir olay olup olmadığı ile ilgili soru işaretleri yaratabilmektedir. Yıldırım çarpması iddiası olan kişinin kesin yaralanma ya da ölüm nedeninin belirlenmesi, yaralanma/ölüm olayında herhangi bir kişinin ya da durumun etkisinin/kusurunun olup olmadığının araştırıması hem tazminat davaları hem de ceza davalarında önem taşımaktadır. Bu tür olgularda olay yerinin dikkatlice araştırıması, şüphe durumunda kişinin kıyafetlerinin muhafaza edilip inceleme için ilgili kuruma gönderilmesi gerekmektedir. Sunulan olgunun askerlik görevi sırasında yaralanması bu durumun kamu adına araştırımasını, gerekli tedbirlerin alınıp alınmadığının değerlendirilmesini zorunlu kılmaktadır.

\section{Sonuç}

Yıldırım çarpması sonucu meydana gelen bulgular, özellikle ülkemizde daha çok ölümle sonuçlanan olgulardaki otopsi bulguları ile sınırlıdır. Olgumuzun yıldırım çarpması sonucu hayatta kalan bir olgu olarak, yıldırım çarpmasına bağlı bulguların tartışımasını sağlaması ve bu tür olguların adli yönünü vurgulaması nedeniyle literatüre katkı sağlayacağı düşünülmektedir.

Çıkar çatışması: Bu olgu, poster bildiri olarak 05 Nisan 2019 tarihinde 16. Adli Bilimler Kongresi'nde sunulmuştur.

\section{Kaynaklar}

1. Cooper MA. A fifth mechanism of lightning injury. Acad Emerg Med 2002; 9 (2): 172-4.

2. Oehmichen M, Auer RN, Konig HG. Special physical trauma-lightning trauma. Forensic Neuropathology and Neurology, Chapter 12. Berlin Heidelberg New York, Springer-Verlag 2006. 256-7.

3. Maio Di Vincent JM, Dana Suzanna E. In: Handbook of forensic pathology. Landes biosciences. 1999. 195-7. 
4. Amber ER, Melinda JM, John GMM, David JB, Leopoldo CC. Lightning injury: A review; Burns. 2008; 34: $585-94$.

5. Elsom DM, Webb JDC. Deaths and injuries from lightning in the UK, 1988-2012. Weather, 2014: 69 (8); 221-6.

6. Lightning-strike-induced acute lung injury: a case report. Uzel Şener M, Demir A, Şener A. Ulus Travma Acil Cerrahi Derg 2019; 25 (2): 198-201.

7. Eke M, Soysal Z. Fiziksel Etkenlerle Oluşan Zararlar. İçinde: Soysal Z, Çakalır C (editörler). Adli tıp. Cilt II, 1. baskı. İstanbul: İstanbul Üniversitesi Cerrahpaşa Tıp Fakültesi Yayınları; 1999. 607-765.

8. Michael J Shkrum, Davi A Ramsay. Forensic Pathology of Trauma. Totowa NJ: Humana Press; 2007: 221.

9. Lewis AM. Understanding the principles of lightning injuries. J Emerg Nurs. 1997; 23 (6): 535-41.

10. Whitcomb D, Martinez JA, Daberkow D. Lightning injuries. South Med J. 2002; 95 (11): 1331-4. 